\title{
Treatment adherence in patients living with HIV/AIDS assisted at a specialized facility in Brazil
}

\author{
Simone Miyada ${ }^{[1]}$, Artênio José Ísper Garbin ${ }^{[1]}$, Renata Colturato Joaquim Gatto ${ }^{[1]}$ \\ and Cléa Adas Saliba Garbin ${ }^{[1]}$
}

[1] Programa de Pós-graduação Stricto Sensu em Odontologia Preventiva e Social, Faculdade de Odontologia de Araçatuba, Universidade Estadual Paulista, Araçatuba, SP, Brasil.

\begin{abstract}
Introduction: In the 1990s, Brazil adopted a public policy that allowed for universal, free access to antiretroviral therapy (ART). Since then, treatment adherence has become a new challenge for administrators of sexually transmitted disease/acquired immunodeficiency syndrome (STD/AIDS) policies. This study quantified adherence to ART and verified whether there is an association between sociodemographic variables and clinical/laboratory data in human immunodeficiency virus (HIV)-infected patients. Methods: This was a cross-sectional, exploratory study with a quantitative approach that was conducted over 8 months. The target population contained patients who were assisted at the ambulatory care facility specialized in STD/AIDS of a mediumsize city located in Northwest São Paulo. In order to verify the level of adherence to ART, a validated CEAT-VIH (Assessment of Adherence to Antiretroviral Therapy Questionnaire) questionnaire was used. Sociodemographic aspects and clinical/laboratory data were obtained from the medical records. The results were analyzed using the Student's t-test and Pearson's coefficient. Results: Herein, 109 patients were interviewed, $56 \%$ of whom were male. The age of the population ranged 18-74 years (mean 45.67 years). Adherence to ART was classified as insufficient in $80.7 \%$ of cases. There was an association between ART adherence and presence of symptoms and/or opportunistic infection $(\mathrm{p}=0.008)$ and economic status $(\mathrm{p}<0.001)$. Conclusions: Adherence to ART among HIV carriers cared for by the public health system is low. Patients who reported a favorable economic status and those without symptoms and/or opportunistic infection demonstrated greater treatment adherence than those who needed to take more than 3 pills a day.
\end{abstract}

Keywords: HIV Seropositivity. Medication adherence. Unified Health System.

\section{INTRODUCTION}

In the 1990s, Brazil adopted a public policy that allowed for universal access to antiretroviral therapy (ART), with free distribution of medication to all people infected with human immunodeficiency virus (HIV). The strategies focused on the prevention of new cases of HIV infection and epidemic control have resulted in a reduction of morbidity, mortality, and hospitalization rates, and thus an increase in life expectancy ${ }^{1}$.

As a consequence of this health policy, treatment adherence has become a new challenge for administrators of sexually transmitted disease (STD)/acquired immunodeficiency syndrome (AIDS) policies as well as for those health services directly involved in assisting HIV carriers in Brazil ${ }^{2}$.

Viral suppression can be achieved as long as there is consistent adherence to ART among the patients. However,

Corresponding author: Profa. Cléa Adas Saliba Garbin.

e-mail: cgarbin@foa.unesp.br

Received 28 June 2017

Accepted 19 September 2017 when medication is taken incorrectly or to an insufficient degree (lapses, not complying with the days and times, etc.), it facilitates virus replication, which may undergo mutations, generating multiresistant strains and consequent therapeutic failure and reducing future treatment options ${ }^{3,4}$.

In Brazil, although a few studies have been conducted to verify the rate of adherence to antiretroviral therapies, this evaluation is currently one of the most impactful efforts to reduce complications and improve the quality of life of people living with HIV/AIDS. Therefore, the aim of this work was to determine the level of adherence to pharmacotherapeutic treatment and ascertain whether there is an association between sociodemographic variables and the clinical data of HIV carriers cared for by the public health system.

\section{METHODS}

This was a cross-sectional, exploratory study with a quantitative approach. The target population was composed of HIV-positive patients registered at an outpatient care facility specializing in STD/AIDS, in a medium-sized city in the northwest region of the Brazilian State of São Paulo. The inclusion criteria were as follows: having an officially registered 
and confirmed HIV diagnosis, age 18 years or older, and agreeing to take part in the study. The exclusion criteria were illiterate status, being in a situation of deprivation of liberty (arrested), and cognitive difficulty. Subjects were recruited via convenience sampling as they came to the facility for treatment. The data collection period was 8 months. Data were collected when patients visited the facility for their medical appointments, in a private room, before the appointment began.

The CEAT-VIH (Assessment of Adherence to Antiretroviral Therapy Questionnaire), validated in Brazil by Remor et al. ${ }^{5}$, was used to determine adherence to treatment. The CEAT-VIH is a self-reported questionnaire comprising 17 questions that assess the level of adherence to antiretroviral treatment. It has a multidimensional character, as it comprises the principal factors that may shape treatment adherence behavior, and consists of five domains: treatment observance (following the instructions to take the medication correctly), history of treatment nonadherence, doctor-patient communication, personal beliefs (treatment expectations), and treatment satisfaction. The final score is obtained by summing all items, the minimum possible score being 17 and maximum 85 . According to the CEAT-VIH, if the gross score is $\geq 80$, the patient is considered highly adherent, and if $<80$, non-adherent (Table 1).

Sociodemographic characteristics and clinical and laboratory data were obtained by analyzing the medical records. Examination results used in this study were those closest in date to the participation in the interviews. Sociodemographic variables included age, sex, level of education, marital status, occupation, ethnicity, sexual orientation, and perception of economic status. The variables related to HIV infection included viral load, CD4 count, presence of symptoms or opportunistic infection in the past few months, number of pills taken, and mode of infection.

The assessment of sociodemographic and (HIV-related) clinical/laboratory variables regarding adherence to treatment was performed using the Student's t-test or the analysis of variance, in the event that there were two or three categories, respectively. Pearson's coefficient was used to verify the correlation between the numeric variables and treatment adherence scores. Statistical tests were performed with a level of significance of $5 \%$.

\section{Ethical considerations}

For the analysis of the data, the software programs Microsoft Office Excel 2016 and Statistica (StatSoft Inc.), version 10, 2011 were employed. The study was approved by the Human Research Ethics Committee (Process FOA02411/2011) and written informed consent was obtained from each participant. All procedures followed were in accordance with the ethical standards of the responsible committee on human experimentation (institutional and national) and with the Helsinki Declaration of 1975, as revised in 2000.

\section{RESULTS}

A total of 109 patients were interviewed, $56.0 \%$ of whom were male. The subjects' ages ranged from 18 to 74 , with the mean age being 45.7. Adherence to antiretroviral treatment was classified as insufficient in $80.7 \%$ of cases (Table 2).
TABLE 1

Classification of level of adherence to antiretroviral therapy.

\begin{tabular}{lc}
\hline Classification of adherence & Adherence score \\
\hline High adherence & $\geq 80$ \\
Non-adherence (insufficient) & $<80$ \\
\hline
\end{tabular}

TABLE 2

Classification of level of adherence to treatment among HIV carriers according to the CEAT-VIH test.

\begin{tabular}{lccc}
\hline Adherence score & Classification & Number & Percentage \\
\hline$\geq 80$ & High adherence & 21 & 19.3 \\
$<80$ & Non-adherence & 88 & 80.7 \\
\hline Total & & $\mathbf{1 0 9}$ & $\mathbf{1 0 0 . 0}$ \\
\hline
\end{tabular}

HIV: human immunodeficiency virus (HIV); CEAT-VIH: Assessing Adherence to Antiretroviral Therapy.

Table 3 shows a selection of measurements depicting total adherence scores according to the categories established for the variables studied. Owing to the small number of individuals in some initially planned categories, we chose to group the subjects into more relevant groups using only two or three categories. The table also displays the $\mathrm{p}$-values obtained from the application of the analysis of variance $\mathrm{t}$-test or F-test, where the variable has 2 or 3 categories, respectively. Our results showed that individuals who reported the absence of opportunistic infections had higher treatment adherence $(\mathrm{p}=0.008)$, as did individuals with a better economic status $(p<0.001)$. Moreover, patients who needed to take more than three pills a day did not demonstrate adverse treatment adherence $(\mathrm{p}=0.053)$, although the result is marginal.

Pearson's coefficient was used to verify correlations between the variables (age, time elapsed since diagnosis, CD4 count, and number of pills), global adherence, and the five dimensions that made up the questionnaire. The data showed a negative correlation for time elapsed since diagnosis and number of pills, and a positive correlation with regard to the CD4 count (Table 4).

\section{DISCUSSION}

In our study, the factors associated with adherence to ART were non-existence of opportunistic infection, economic status, and the number of pills taken daily. Considering the findings of this study, we ascertained that the patients' sociodemographic profiles (age and sex) resemble that of patients from other studies $^{6-8}$ with similar goals and which used the same tool (CEAT-VIH) to investigate drug therapy adherence in different regions of the country (northeast and south).

The age range of people who live with HIV/AIDS (PLHA) in Brazil differs from that in scientific research data as well as data provided by government information systems. The mean age obtained in the present study was 45.67 years, in agreement 
TABLE 3

Frequency and percentage of individuals in the two categories of variables in this study and descriptive statistics of treatment adherence scores.

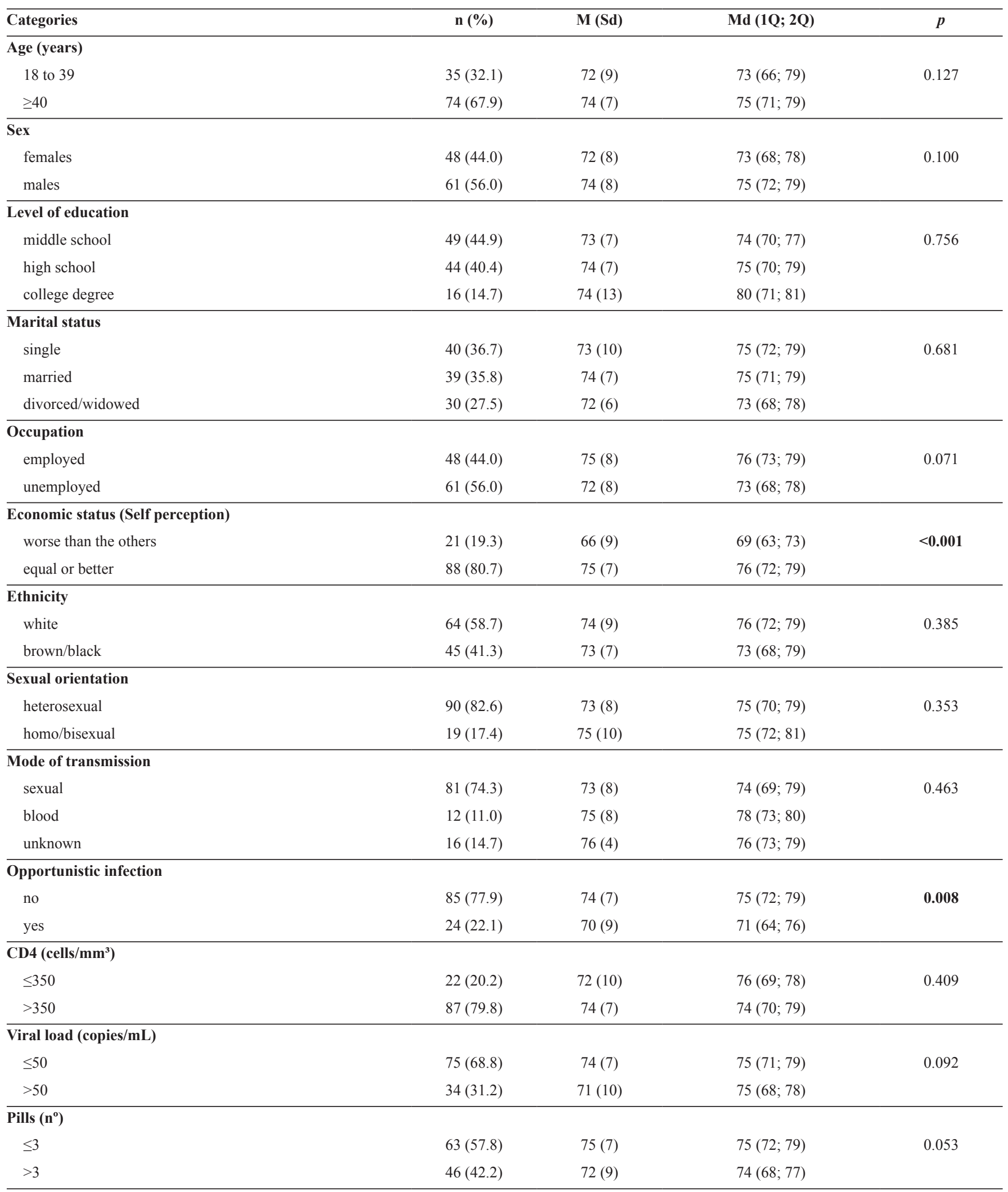

N: frequency; \%: percentage; M: mean; Sd: standard deviation, Md: median; Q: quartile; CD4: cluster of differentiation 4; ANOVA: analysis of variance.

*Significant at the level of 5\% (Student's t-test was applied for dichotomous variables or ANOVA in the case of two or more categories) 
TABLE 4

Descriptive statistics of numeric variables and their correlation coefficients with global adherence and other domains.

\begin{tabular}{lcccccccc}
\hline Variable & M (Sd) & Md (1Q, 2Q) & D1 & D2 & D3 & D4 & D5 & D6 \\
\hline Age (years) & $45(12)$ & $47(36 ; 53)$ & 0.065 & 0.073 & 0.129 & -0.062 & 0.077 & -0.069 \\
Time (years) & $9(7)$ & $8(3 ; 13)$ & -0.132 & -0.134 & -0.005 & -0.058 & $-\mathbf{0 . 2 4 2 *}$ & 0.031 \\
CD4 count (cells $\left./ \mathrm{mm}^{3}\right)$ & $646(335)$ & $635(426 ; 869)$ & -0.037 & -0.051 & -0.138 & $\mathbf{0 . 2 5 1 *}$ & -0.064 & -0.013 \\
Pills (n & $3(2)$ & $3(3 ; 4)$ & $-\mathbf{0 . 2 1 3 *}$ & $-\mathbf{0 . 2 2 0}$ & -0.173 & -0.014 & $-\mathbf{0 . 2 2 9 *}$ & -0.019 \\
\hline
\end{tabular}

M: mean; Sd: standard deviation, Md: median; Q: quartile; D1: global adherence; D2: treatment observance; D3: antecedents of non-adherence; D4: doctorpatient communication; D5: personal beliefs; D6: treatment satisfaction; CD4: cluster of differentiation 4 . *Significant correlation at the level of 5\%.

with other national studies ${ }^{8-10}$, in which the largest proportions of PLHA were aged between 30 and 49 years. However, data presented in the last HIV/AIDS epidemiological bulletin, published by the Ministry of Health in 2016, show that the highest concentration of HIV cases in Brazil is in individuals aged between 25 and 39 years, for both sexes ${ }^{11}$. In the last few decades, there has also been an increase in the number of children between the ages of 0 and 14 infected by HIV as a result of vertical transmission, due to the increase in infected women of childbearing age (15 to 49 years) $)^{12}$.

The low prevalence of HIV infection in the male sex demonstrates that the disease profile has been changing, in which feminization is evident ${ }^{13}$. Although at the beginning of the epidemic homosexual men were most commonly affected by HIV, the current proportion of infected men and women is very similar ${ }^{14,15}$. The same is true for the majority of the participants declared as heterosexual $(82.6 \%)$ and not having a stable partner-single (36.7\%) (Table 3).

This new reality demonstrates the transitional nature of the disease, in which the idea of there being specific risk groups (homosexuals and users of injectable drugs) has given way to the notion of risky behavior (unprotected sex) ${ }^{16}$. This fact can also be demonstrated in the results of this investigation, as the majority of participants $(74.3 \%)$ reported having been sexually infected (Table 3). This mode of infection is responsible for most new cases of infection worldwide. The frequency of heterosexual transmission is growing and women are more becoming vulnerable to being infected by their male partners rather than the other way around ${ }^{17}$. For many couples, unprotected sex can be interpreted as intimacy and confidence, resulting in a barrier to the use of condoms ${ }^{17,18}$. Therefore, measures to raise awareness among the general population to prevent the risk of new infections must be predicated principally on risky sexual behavior.

As for the level of instruction, 55.1\% of the participants completed secondary education or higher (graduate-level and/ or postgraduate education), and the highest percentage of Brazilians infected by HIV in 2016 had completed secondary education ${ }^{11}$. This fact contradicts the country's tendency towards the pauperization of the epidemic, i.e. the growing dissemination of HIV in the population with low levels of education ${ }^{6}$. Thus, it is important that the campaigns for awareness and prevention in combatting HIV be directed to the whole population, regardless of social vulnerability.

One of the most important findings of this study was the high level of non-adherence to antiretroviral treatment (80.7\%). Other similar studies, conducted in different regions of Brazil, which used the same tool to observe adherence to ART, found lower values, such as that of Moraes et al. ${ }^{8}$, who observed an unsatisfying and low adherence rate in $71.3 \%$ of patients investigated, while Galvão et al. ${ }^{19}$, found inadequate adherence in $51.3 \%$ of individuals. Jacques et al. ${ }^{6}$, revealed, in their study, a high level of adherence (75.7\%). Several factors may significantly affect adherence to treatment such as patient traits (sociodemographic and psychosocial factors), patient-health professional relationships (confidence and confidentiality), health-related factors, diseaserelated characteristics (HIV-related symptoms), and therapyrelated factors (number of pills and side effects of medication) ${ }^{20}$.

Those who presented no symptoms and/or opportunistic infection demonstrated better adherence. Therefore, patients who correctly take their medication present better systemic conditions, as would be expected, because the efficiency of ART depends directly on patient adherence. In order to maintain an undetectable viral load, the patient must take at least $95 \%$ of the prescribed medication ${ }^{6}$, which leads to a decrease in hospitalization rates due to opportunistic infection, as well as a decrease in mortality rate re $^{21}$.

We also observed an association between economic status and treatment adherence: the better the economic status, the higher the adherence. Probst et al. ${ }^{22}$ performed a meta-analysis in order to ascertain the influence of socioeconomic status on the HIV mortality rate in South Africa and observed that lowincome individuals had a 50\% higher chance of dying from HIV infection than people with a better economic status. Thus, people receiving a low income constantly deal with limited resources, which may negatively interfere with self-care of the disease. AIDS treatment is complex and involves several variables such as medical follow-up, withdrawal of medication at the health facility, regular use of the medication at the times prescribed by the doctor, and collection of blood for supplementary examinations, among other forms of care, according to the patient's health. All these factors may negatively interfere with the working routine of seropositive patients and, as a result, self-care may be neglected. 
Moreover, there was a negative correlation between the number of pills to be taken daily and global adherence to treatment; individuals who needed to take more than 3 ART pills a day showed lower treatment adherence. The use of multiple medications exposes the patient to a more complex treatment, which requires greater attention, memory, and organization with regard to the times to administer the drugs ${ }^{23}$. Moreover, the possibility of triggering side effects increases ${ }^{24}$. For each pill taken, the risk of non-adherence increases by $12 \%{ }^{25}$.

In addition, there was a negative correlation between time elapsed since diagnosis and personal beliefs. Patients who were diagnosed with HIV more recently presented positive expectations of the treatment. This may be explained by the current advances in medicine in combatting HIV, by the free distribution of medication by the public health system, and by the ease of access to treatment. All these factors converge towards a decrease in mortality rates and hospitalization due to opportunistic infections ${ }^{1}$. At the beginning of the epidemic, the image associated with the seropositive patient was that of fragile people in a terminal state in hospital beds, waiting to die. Nowadays, owing to the chronification of HIV infection, this association is no longer applicable ${ }^{26}$.

The health professional has an important role, together with the patient, in terms of maintaining and adhering to ART. The results obtained in this study demonstrated a positive correlation between the number of CD4 lymphocytes and better professional-patient communication. This leads us to infer that patients with better systemic conditions are more satisfied with the treatment received from the professional team that is caring for them. Professional-patient relations are a facilitating agent in adherence to therapy because, as the patient's doubts and needs are addressed and supported, a trusting relationship and a feeling of belonging are created, which is fundamental to the success of such a complex therapy ${ }^{27}$. Nevertheless, it is important to emphasize that the patient's level of adherence to ART cannot be definitive in nature as it may vary at any time during the treatment. Therefore, adherence must be constantly stimulated by the health professionals, who must always be aware, in order to take co-responsibility for either the success or the failure of therapy ${ }^{6}$.

For PLHA in Brazil, the national health policy provides universal access to treatment through the free distribution of medication, multidisciplinary care at specialized facilities, as well as prevention campaigns and rapid diagnosis tests. Nonetheless, if adherence to treatment is not high enough for ART to be effective, all this investment may be jeopardized since the irregular use or the insufficient number of doses may lead to the development of resistant HIV viruses ${ }^{28,29}$. Thus, we must highlight the importance of this study, as the constant monitoring of adherence to ART in different regions of the country can direct the government's actions so that the investment is not jeopardized.

The data obtained show that adherence to ART is low in those patients who attend the outpatient care facility (SAE/SUS) investigated in this study. The patients who reported having a favorable economic status and those with no symptoms or opportunistic infection presented better adherence to ART, while the adherence of those who needed to take more than 3 pills a day was worse. These results indicate the need to intervene with public actions directed towards the population in question, seeking to contribute with increased adherence to drug therapy. Even though the patient is the focus of the treatment, the team of health professionals must take co-responsibility for this process.

Some limiting factors should be considered, such as the fact that the results of this study cannot be generalized to other locations; however, it is important to stress the need to compare the results of this study with those of other studies with similar goals conducted in Brazil and other countries.

\section{Acknowledgments}

We offer our deepest thanks to the Coordenação de Aperfeiçoamento de Pessoal de Nível Superior (CAPES) for the masters scholarship grant.

\section{Conflict of interest}

The authors declare that there is no conflict of interest.

\section{REFERENCES}

1. Grangeiro A, Escuder MM, Cassanote AJF, Souza RA, Kalichman AO, Veloso V, et al. The HIV-Brazil Cohort Study: Design, Methods and Participant Characteristics. PLoS One. 2014;9(5):e95673.

2. Remor E. Valoración de la adhesión al tratamiento antirretroviral en pacientes VIH+. Psicothema. 2002;14(2):262-7.

3. Chesney MA, Morin M, Sherr L. Adherence to HIV combination therapy. Soc Sci Med. 2000;50(11):1599-605.

4. Fonseca LC, Martins FJ, Vieira RCPA, Pereira RMC, Ferreira AS, Raposo NRB. Evaluation of inadequate anti-retroviral treatment in patients with HIV/AIDS. Rev Soc Bras Med Trop. 2012;45(2):151-5.

5. Remor E, Milner-Moskovic J, Preussler G. Adaptação brasileira do "Cuestionario para la evaluación de la adhesión al tratamiento antiretroviral”. Rev Saude Publica. 2007;41(5):685-94.

6. Jacques IJAA, de Santana JM, Moraes DCA, Souza AFM, Abrão FMS, Oliveira RC. Avaliação da Adesão à Terapia Antirretroviral entre Pacientes em Atendimento Ambulatorial. R Bras Ci Saude. 2014;18(4):303-8.

7. Calvetti PU, Giovelli GRM, Gauer GJC, Moraes JFD. Psychosocial factors associated with adherence to treatment and quality of life in people living with HIV/AIDS in Brazil. J Bras Psiquiatr. 2014;63(1):8-15.

8. Moraes DCA, Oliveira RC, Motta MCS, Ferreira OLC, Andrade MS. Terapia antirretroviral: a associação entre o conhecimento e a adesão. Rev. Pesqui. Cuid. Fundam. 2015;7(4):3563-73.

9. Santos VF, Galvão MTG, Cunha GH, Lima ICV, Gir E. Efeito do álcool em pessoas com HIV: tratamento e qualidade de vida. Acta Paul Enferm. 2017;30(1):94-100.

10. Foresto JS, Melo ES, Costa CRB, Antonini M, Gir E, Reis RK. Adesão à terapêutica antirretroviral de pessoas vivendo com HIV/ aids em um município do interior paulista. Rev. Gaúcha Enferm. 2017;38(1):e63158.

11. Ministério da Saúde. Secretaria de Vigilância em Saúde. [Internet] Boletim Epidemiológico - Aids e DST Ano V - n $1-27^{\mathrm{a}}$ a $53^{\mathrm{a}}$ semanas epidemiológicas - julho a dezembro de 2015 Ano V - 
$\mathrm{n}^{\mathrm{o}} 1-01^{\mathrm{a}}$ a $26^{\mathrm{a}}$ - semanas epidemiológicas - janeiro a junho de 2016. [Citado em 30 de janeiro de 2017] Disponível em: http:// www.aids.gov.br/sites/default/files/anexos/publicacao/2016/59291/ boletim_2016_1_pdf_16375.pdf.

12. Joint United Nation Programme on HIV/AIDS (UNAIDS). Global AIDS response progress reporting 2014: construction of core indicators for monitoring the 2011 United Nations political declaration on HIV/AIDS. [Internet]. Geneva: UNAIDS; 2014 [Cited 2017 Jan 30] Available from: http://www.unaids.org/sites/ default/files/media_asset/GARPR_2014_guidelines_en_0.pdf

13. Carvalho CV, Merchán-Hamann E, Matsushita R. Determinantes da adesão ao tratamento anti-retroviral em Brasília, DF: um estudo de caso-controle. Rev Soc Bras Med Trop. 2007;40(5):555-5.

14. Santos NJ, Barbosa RM, Pinho A, Villela WV, Aidar T, Filipe E. Contextos de vulnerabilidade para o HIV entre mulheres brasileiras. Cad Saude Publica. 2009;25(Supl 2):321-33.

15. Villela WV, Barbosa RM. Trajetórias de mulheres vivendo com HIV/aids no Brasil. Avanços e permanências da resposta à epidemia. Cien Saude Colet. 2017;22(1):87-96.

16. Camargo LA, Capitão CG, Filipe EMV. Saúde mental, suporte familiar e adesão ao tratamento: associações no contexto HIV/Aids. Psico-USF. 2014;19(2):221-32.

17. Lacroix JM, Pellowski JA, Lennon CA, Johnson BT. Behavioural interventions to reduce sexual risk for HIV in heterosexual couples: a meta-analysis. Sex Transm Infect. 2013;89(8):620-7.

18. Reis RK, Melo ES, Gir E. Fatores associados ao uso inconsistente do preservativo entre pessoas vivendo com HIV/Aids. Rev Bras Enferm. 2016;69(1):47-53.

19. Galvão MTG, Soares LL, Pedrosa SC, Fiuza MLT, Lemos LA. Qualidade de vida e adesão à medicação antirretroviral em pessoas com HIV. Acta paul. Enferm. 2015; 28(1): 48-53.

20. Koole O, Denison JA, Menten J, Tsui S, Wabwire-Mangen F, Kwesigabo G, et al. Reasons for Missing Antiretroviral Therapy:
Results from a Multi-Country Study in Tanzania, Uganda, and Zambia. PLoS One. 2016;11(1):e0147309.

21. Marins, JR, Jamal L, Chen S, Barros M, Hudes E, Barbosa A, et.al. Dramatic improvement in survival among adult Brazilian AIDS patients. AIDS. 2003;17(11):1675-82.

22. Probst C, Parry DH, Rehm J. Socio-economic differences in HIV/AIDS mortality in South Africa. Trop Med Int Health. 2016;21(7):846-55.

23. Rocha CH, Oliveira APS, Ferreira C, Faggiani FT, Schtoeter G, Souza ACA, et. al. Adesão à prescrição médica em idosos de Porto Alegre, RS. Cienc Saude Colet. 2008;13(Sup):703-10.

24. Gomes VF, Miguel TLB, Miasso AI. Transtornos Mentais Comuns: perfil sociodemográfico e farmacoterapêutico. Rev Latino-Am Enfermagem. 2013;21(6):1203-11.

25. Colombrini MRC, Lopes MHBM, Figueiredo RM. Adesão à terapia antiretroviral para HIV/Aids. Rev Esc Enferm USP. 2006;40(4): 576-81.

26. Soares GB, Garbin CAS, Rovida TAS, Garbin AJÍ. Qualidade de vida de pessoas que vivem com HIV/AIDS assistidas no serviço especializado em Vitória (ES), Brasil. Cien Saude Colet. 2015;20(4):1075-84.

27. Bonolo PF, Gomes RRFM, Guimaraes MDC. Adesão à terapia anti-retroviral (HIV/aids): fatores associados e medidas da adesão. Epidemiol Serv Saúde. 2007;16(4): 267-78.

28. Nemes MIB, Castanheira ERL, Helena ETS, Melchior R, Caraciolo JMC, Basso CR, et al. Adesão ao tratamento, acesso e qualidade da assistência em AIDS no Brasil. Rev Assoc Med Bras. 2009;55(2):207-12.

29. Cancian NR, Beck ST, Santos GS, Bandeira D. Importância da atenção multidisciplinar para resgatar o paciente com HIV/AIDS apresentando baixa adesão à terapia antirretroviral. Rev de Atenção à Saúde. 2015;13(45):55-60. 